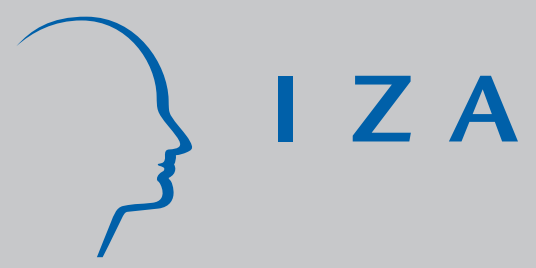

IZA DP No. 1039

Institutional Uncertainty and European

Social Union: Impacts on J ob Creation and Destruction in the CEECs

Ansgar Belke

Matthias Göcke

Martin Hebler

March 2004 


\title{
Institutional Uncertainty and European Social Union: Impacts on Job Creation and Destruction in the CEECs
}

\author{
Ansgar Belke \\ University of Hohenheim \\ and IZA Bonn \\ Matthias Göcke \\ University of Münster \\ Martin Hebler \\ Technologiezentrum Wuppertal
}
Discussion Paper No. 1039
March 2004

\author{
IZA \\ P.O. Box 7240 \\ 53072 Bonn \\ Germany \\ Phone: +49-228-3894-0 \\ Fax: +49-228-3894-180 \\ Email: iza@iza.org
}

\begin{abstract}
Any opinions expressed here are those of the author(s) and not those of the institute. Research disseminated by IZA may include views on policy, but the institute itself takes no institutional policy positions.

The Institute for the Study of Labor (IZA) in Bonn is a local and virtual international research center and a place of communication between science, politics and business. IZA is an independent nonprofit company supported by Deutsche Post World Net. The center is associated with the University of Bonn and offers a stimulating research environment through its research networks, research support, and visitors and doctoral programs. IZA engages in (i) original and internationally competitive research in all fields of labor economics, (ii) development of policy concepts, and (iii) dissemination of research results and concepts to the interested public.
\end{abstract}

IZA Discussion Papers often represent preliminary work and are circulated to encourage discussion. Citation of such a paper should account for its provisional character. A revised version may be available on the IZA website (www.iza.org) or directly from the author. 


\title{
ABSTRACT
}

\section{Institutional Uncertainty and European Social Union: Impacts on Job Creation and Destruction in the CEECs ${ }^{*}$}

\begin{abstract}
With the extension of its competence for social policy legislation in the Maastricht and Amsterdam treaties, the EU has adopted a significantly new social dimension in the past ten years. According to the Copenhagen criteria, the CEEC candidate countries have to adopt the former via the acquis communautaire. This paper discusses the effect of an adoption of this EU social law on future labor market performance in the CEECs. For this purpose, we model and investigate the impact of institutional uncertainty (and of its elimination) on job creation and job destruction in the CEEC candidate countries. We conclude that structural change on CEEC labor markets tends to be fostered via reducing institutional uncertainty. However, these kinds of benefits of the adoption of the acquis have to be weighed against the danger that the adoption of inefficient EU social and labor policy regulations imposed by the acquis might also entail significant risks for employment in the CEECs similar to those which have materialized in the former EU. This rather pessimistic view can be substantiated based on a public choice analysis of why the old EU members will want to impose the Social Charter even though it will harm the new members. These risks consist of a significant increase in hiring and firing costs and of higher wage rates. Based on a simple option value analysis, we investigate and evaluate the trade-off between lower institutional uncertainty and higher employment costs induced by the adoption of the acquis.
\end{abstract}

JEL Classification: D81, J23, P26

Keywords: EU enlargement, real option approach, social union, institutional uncertainty

Corresponding author:

Ansgar Belke

Department of Economics

University of Hohenheim

Museumsflügel

70599 Stuttgart

Germany

Tel.: +497114593246

Fax: +497114593815

Email: belke@uni-hohenheim.de

\footnotetext{
${ }^{*}$ Paper prepared for the ZEI Conference on "Political Economy of Transitions: Job Creation and Job Destruction", Bonn, August 14-17, 2003. The authors thank the participants for helpful comments. The usual caveats apply.
} 


\section{Introduction}

Market economy rules are urgently required in Central and Eastern European countries (CEECs) in order to eliminate the prevailing institutional, i.e. legal, uncertainty which currently restrains investment. Consequently, the transfer of a set of rules such as the acquis communautaire as a prerequisite for their EU entry might be justified if we interpret it as a reliable obligation and as a commitment to the transformation process (Baldwin et al. 1997, pp. 169 ff.; Kohler 1999, p. 2). While it took the EU approximately 50 years to establish these institutions, the CEECs are required to realize this transformation in just a few years in order to fulfill the Copenhagen criteria (Martens 2000, p. 3). Hence, an institutional peg like the adoption of the acquis communautaire seems to make sense.

On the other hand, a counteracting effect results from the fact that the adoption of the acquis will tend to increase hiring and firing costs and wage rates in the new EU member countries. This assumption is based on our analysis of EU social policy. Since its beginnings in 1992 there have been numerous regulations enacted that create seriously employment-endangering labor market rigidities. At the same time they are protecting the employed insiders from the 'rich' EU-countries against the competition by employees from the 'poorer' member countries.

We model and investigate the impact of institutional uncertainty (and of its elimination), increasing labor markets rigidities and increasing wages on job creation and job destruction in the CEEC candidate countries. In our model, non-linearities in the relation between employment in the CEECs and its explaining variables like firm revenues and wages are emphasized. A potential mechanism based on a band of inaction that is induced by sunk costs and could account for a 'weaker' relationship between employment and its determinants is augmented by institutional uncertainty. As a result of option value effects the band of inaction is widened and, thus, hysteresis effects are strongly amplified by uncertainty. Conversely, the adoption of the acquis is shown to weaken hysteresis effects on the CEEC labor markets, at least as the elimination of institutional uncertainty is taken into account. However, one has to work on the assumption that rigidities increase. Ceteris paribus, the latter leads to a widening of the 'band of inaction' and, thus, preserves given structures. However, it cannot be determined a priori which effect dominates. The probable increase of the wage costs effects an upward movement of the band of inaction. This means an amplification of job-destruction, but at the same time a mitigation of job-creation. Moreover, it elucidates the danger of a "Mezzogiorno" respectively of a "German unification" effect, i.e. a strong decline of jobs and high unemployment induced by excessive wage costs.

The paper proceeds as follows. In the following chapter we give evidence for the assumption that the increase in EU social legislation since 1992 reduces labor markets adjustment capabilities. In chapter 3 we outline the basic model of job destruction and creation based on the option value of waiting. In chapter 4 the scenario of EU Eastern Enlargement is analyzed 
for impacts on job creation and job destruction. In chapter 5 the results are illustrated by calculating a simple numerical example. In chapter 6 we summarize our conclusions.

\section{Labor market effects of the adoption of the EU's social policy}

\subsection{The legal status of the European Social Policy}

The "Treaty Establishing the European Community" (ECT) of October $2^{\text {nd }} 1997$ clearly applies to "fundamental social rights such as those set out in the European Social Charter signed at Turin on $18^{\text {th }}$ October 1961 and in the 1989 Community Charter of the Fundamental Social Rights of Workers" (Article 136 ECT). By means of Article 136 ECT two reliable sources of the EU social policy are specified. First, the European Social Charter of 1961 is an agreement between the members of the Council of Europe, which has been signed by $32 \mathrm{EU}$ member states and has been ratified by 26 to date. An extended version was passed on May $3^{\text {rd }} 1996$ in Strasbourg and has been signed in the meantime by 32 countries and ratified by 15. ${ }^{1}$ Since in both contracts a derogation right is explicitly intended with respect to the acceptance of individual principles and the Council of Europe does not have any serious competence of sanctions against its members at its disposal, an analysis of the total package, as it is done by Boeri et al. (1998), p. 92, seems to be hardly meaningful. ${ }^{2}$ Second, on December $9^{\text {th }} 1989$ in Strasbourg a "Community Charter of Fundamental Social Rights of Workers" was passed as a declaration. This so-called EU Social Charter was not signed by the United Kingdom, reducing the meaning of this charter further to symbolic significance. Although the United Kingdom announced to sign the Charter in 1998 in the wake of the election of Tony Blair, it has not yet put this decision into practice. Consequently, neither the European Social Charter nor the EU Social Charter appear to be the relevant governance arrangements for the detailed analysis of the EU social policy, even though the wording of the ECT explicitly refers to them.

But the EU social charter is nonetheless important, because it can be seen as a starting point as well as a target agreement for EU social policy. Before the signing of the Maastricht Treaty, an "Agreement on Social Policy" was passed - again without the United Kingdom which expressed the intend to implement the EU Social Charter based on the acquis (preamble). This agreement was ratified and integrated in the "Maastricht Treaty on European Union" (TEU) by means of the "Protocol on Social Policy" on February $7^{\text {th }} 1992$. By this unique construction of law the areas of competence of the Community with respect to social policy were expanded without validity for the U.K. (Heise 1998, p. 12). After the election of

1 All ten EU candidates from Central and Eastern Europe are members of the Council of Europe and have either signed the Social Charter of 1961, of 1996 or both. See http://conventions.coe.int/Treaty/EN/cadreprincipal.htm.

2 Particularly, the authors predominantly refer to the version of 1996 which is not mentioned in the ECT (see Boeri et al. 1998, p. 92). 
Tony Blair in 1997, the U.K. declared its willingness to support the common social policy. Since the signing of the "Treaty of Amsterdam" on October $2^{\text {nd }} 1997$, by which the "Agreement on Social Policy" was integrated into the ECT (Article 136) largely word-forword with only a few modifications, all social policy resolutions of the EU are again valid for all EU member states to the same extent and "the social chapter (...) is now integral to the EU's constitutional acts" (Lavigne 1998, p. 41, Feldmann 1999, p. 670).

Therefore, although the important step concerned the legal changes wrought by the Treaty of Amsterdam, the legal status of EU social policy is defined by the social chapter of the ECT. The social chapter is the tool to implement the social charter. In other words, although the social charter is non-binding yet it is nevertheless important for EU labor markets (today and in the future).

\subsection{The new dimension of the EU's social policy}

The area of legislative competence of the EU with concerning social policy has been enlarged by the Protocol on Social Policy and the Social Chapter of the Treaty of Amsterdam in several fields (Article $137 \mathrm{ECT}$ ). As a result, the EU now has new possibilities to enact restrictions of freedom of action in individual employment contracts by directives. Before 1992, this was possible only in a rather limited area, mostly in the fields of safety at work and of conditions for workers moving within the Community. It is of special significance in regard to the topic of our paper that the EU provides for the inclusion of unions and employers' associations in social legislation.

It is pointed out frequently that the workers' and employers' organizations up to now have no rights for collective bargaining on the level of the EU. This view can be confuted with regard to Article 4 (1) Protocol on Social Policy respectively Article 139 (1) ECT. ${ }^{3}$ However, it can be demonstrated that these agreements will be non-binding for third parties which are nonmembers of the parties to the contract. This means that the realization of the bargaining results is not at all guaranteed. Once more, the validity of this view can be quickly rejected: the workers' and employers' associations are granted for the first time the possibility to transform their agreements in the (enlarged) area of legislative competence of the EU into council directives on the basis of Article 4 (2) social protocol respectively Article 139 (2) ECT. ${ }^{4}$ Consequently, the prospect that national social standards will quickly become hardly reversible international rules, if this is pushed forward by supranational collective pressure groups can be assessed as rather high. Under the condition of a resolution of the Council of Ministers, these agreements become binding also for third parties which are non-members of the parties to the contract. A further serious objection could be that the responsibility for

3 "Should management and labour so desire, the dialogue between them at Community level may lead to contractual relations, including agreements." [Art. 139 (1) ECT].

4 Beginning in 1996 this happened several times so far. 
reaching wage agreements with respect to working conditions is now wholly ascribed to the Council of Ministers and the Commission. One possible effect will be the standardization of working conditions in the EU.

Since 1992, the EU Commission passed several directives and regulations, based on its enlarged competencies. For purposes of illustration it makes sense to assess some of these directives with regard to their labor market effects.

1. Some of the directives express Europe's striving for solidarity and the effort to grasp and formulate this into a common doctrine. An integration of the CEECs implies a common and uniform attitude towards the interpretation of a 'European labor market and social politics', from this point of view. The directives include several regulations, which are separately and from a legal point of view not yet specific enough to be acutely employment-endangering, but force the member countries to a common lower bound for 'conditions of work' (Belke 1998, p. 220).

2. Several directives, however, create seriously employment-endangering labor market rigidities while simultaneously protecting the employed insiders from the 'rich' EU-countries against the competition by employees from the 'poorer' member countries (Burda 1998, p. 18). The implementation of the Social Charter is obviously carried out more pressingly, the closer the entry date of the CEECs becomes. The EU Commission launched a whole series of suggestions in March 1998 in order to enlarge the working time directive of 1993 to employees who had been excluded so far. Furthermore, different directives expanded vacation, pension and dismissal regulations to some so far excluded plants or divisions of enterprises (Burda 1998, p. 18).

Directives and regulations can be seen as the attempt of some of the established EU-countries to export labor market rigidities, i.e. significant hiring and firing costs and also higher minimum wages, to poorer and 'catching up' economies. This view is of special importance with respect to the topic of our paper. Originally, poorer countries offer a more competitive production environment because of lower labor costs and lower standards of living. Established EU members accept that unemployment will be high and lasting in the CEECs after their accession to prevent wages and social standards in the EU from being 'eroded'.

\subsection{Status quo and future scenarios of the labor markets of the CEECs}

The future dynamics of labor market performance in the CEECs will still differ from the EU to a certain extent, mainly for the following reasons. First, the transformation recession determined by special factors like the collapse of the former Soviet Union and connected with fiscal and balance of payment problems, wars in the Gulf and above all in the Balkans region still prevents the recovery of labor demand (path dependence; problems of hysteresis). To this extent, the CEECs resemble East Germany. Second, job elimination and job creation in the CEECs are connected by endogenous feedback because of fiscal policy (fiscal trap). A 
particular feature of the CEECs as compared to the EU economies is the fact that the state lost a major share of its sources of income due to the transformation and the take-over of large parts of the economies by private owners and managers. For political and economic reasons, this led either directly or indirectly, via contributions to different social funds to an increase in the taxation of labor. Since this kind of duty can strictly be collected more easily than the usual value-added or the income tax, the governments of the CEECs have become increasingly dependent on these revenues in the recent past. When the financial burdens of unemployment insurance and benefits became pressingly high in the course of transition, and as a consequence tax revenues diminished (above all in Hungary and Poland), the taxation of labor and thus the non-wage labor costs rised again as a reaction. This lowered the demand for labor further, which led to the dynamic instability of the whole system. For the CEECs, in contrast to analysis for the OECD (Nickell and Bell 1997), a significant and negative impact of the taxation of labor on employee-employer relationships cannot be rejected empirically. Employment in these countries often fell into the so-called fiscal trap, i.e. into an equilibrium with excessive taxation and tax evasion. In this connection, the emergence of a comprehensive shadow economy as an evasive action with respect to the increasing taxation of labor can be seen as typical of the CEECs (Boeri et al. 1998, p. 86; Burda 1998, p. 10). In this respect, the CEECs are strongly similar to the Italian Mezzogiorno and their labor markets are characterized by an extraordinary high need of adjustment capabilities (Belke and Hebler 2000).

By now, the labor markets in the CEECs resemble the labor markets of Western Europe in many aspects. The search incentives caused by the wage compensation schemes in most CEEC's are as low as in Continental EU-member states. The employee protection legislation in most CEECs follows the Continental European style. Particularly some rules concerning severance pay and protection against unlawful dismissal follow Continental European models word-for-word (Boeri et al. 1998, p. 88). As in Western Europe, inefficient active labor market policies (ALMPs) were selected to mix-up stagnating unemployment pools. Additionally, the mobility of workers is even lower than in Western Europe. Empirical analysis has shown that the macroeconomic adjustment on labor markets is similar to Western Europe due to the fact that the burden of this adjustment is mainly borne by the decision of active participation in the labor market. As in Western Europe, the flexibility of wages so far cannot play a prominent role in adjustment processes. Overall, thus, one can conclude that the labor markets of the CEECs are predominantly typically Western European (Huber 1999, p. 12). Hence, the diagnosis is also one of high hiring and firing costs and on average higher wages ("eurosclerosis").

That is why, unfortunately from a market economist's point of view, it can be seen as a safe bet that the enlargement will not lead to a 'competition of institutions' simply because there is no 'trade-off' between Western and Eastern institutions. Western institutions are a conditio sine qua non for accession countries either via the acquis or, expressed more generally, by 
Western democratic standards. As such they are not negotiable. However, the enlargement will most likely at the same time raise competition on several markets, including the labor markets. Hence we feel autorized to state that "Europe as a whole is facing the same challenge" (Franz 1995, p. 43). ${ }^{5}$

Any adverse shocks to labor markets, for example, due to competition of imports, can have persistent consequences under these circumstances. If these shocks mainly concern small regions they can result in local and extremely persistent unemployment. Hence, Eastern enlargement is frequently said to imply roughly the same chances and risks for the CEECs as for the EU15. The fast 'return to Europe' of the CEECs will from the beginning constitute an integration shock for the European labor markets as a whole. To what extent this assessment is right, will be investigated in this paper more deeply based on an explicit model. According to our model, the relationship between institutional uncertainty and employment should be particularly strong if the labor market is characterized by rigidities that, e.g., improve the bargaining position of workers. Labor markets of most of the current EU members are usually considered to be too rigid and, thus, give leeway to the functioning of the mechanism explained in the model. Where do the candidates stand in this respect?

\subsection{Are we legitimized to apply the model to the CEEC labor markets?}

Can our above considerations be reconciled with current empirical evidence on institutions in the CEECs? Riboud et al. (2002) deliver an insightful study in this respect. They attempt to assess the flexibility of the labor market institutions in six CEE candidate countries (the Czech Republic, Estonia, Hungary, Poland, Slovakia and Slovenia). ${ }^{6}$ According to their findings, these countries fall somewhere in the middle of the flexibility scale compared to the OECD economies. Though, they do not reach the level of flexibility of the UK, Ireland and Denmark, they still exhibit much greater flexibility than the Club Med countries, France and Germany). ${ }^{7}$ As regards the unemployment insurance systems, the CEECs seem to be less generous than the OECD or the EU countries. They also spend less on both passive and active employment policies. Also in terms of the role of the unions in the wage negotiation process,

5 The only limitations for our main argument might arise from the fact that employee protection legislation in most CEECs is not yet applied as strictly as in the EU (Burda 1998, p. 15). Additionally, meaningful exceptions for small and foreign enterprises are made and the regulation of part-time work, at least in Poland, Hungary and the Czech Republic, is handled in a more flexible manner than in most Western European countries (OECD 1999, p. 57). In this respect, the CEECs are strikingly similar to Eastern Germany in the second half of the nineties. However, it can as in the case of the ex-GDR be concluded that currently (i.e. before accession) the labor markets of the CEECs are in general not as flexible as they should be to achieve full employment in the near future.

6 In order to allow for a comparison with the developed economies they made use of the OECD methodology (1999).

7 However, in terms of employment protection legislation, Slovenia belongs to those countries with the highest degree of inflexibility. This could somewhat change if the new proposed labor code, introducing much more flexible provisions for both permanent and temporary contracts, is approved (Boeri and Terrell 2002). 
the candidates fall somewhere in the middle of the range of the OECD countries. However, they have extremely high payroll and also other taxes which even exceed the highest levels in the EU and, even more important in our context, rigid employment protection legislation.

Moreover, the most important point with respect to our model is that the CEE candidate countries generally opted for labor market institutions common in the Western Europe, which might be on the one hand due to cultural and geographical proximity and on the other hand driven by manifest interests of West European employer's and associations and unions. This clearly increases the costs of job creation and destruction and the fallback reservation wage, i.e. the minimum wage requested by a person looking for a job and is further supported by the fact that they are required, prior to their entry into the EU, to align their legislation with the acquis communautaire which includes a number of provisions regarding the labor market regulations. This kind of legislation has favored employment protection while taxing employers heavily. Many of the rules governing labor markets in the CEECs raise labor costs, create barriers to entry and exit, and, hence, introduce rigidities in the employment structure. Thus, the candidate countries have introduced the similar rigidities that are troubling the EU countries (Belke and Hebler 2001 and 2002; Riboud et al. 2002). By this, employment decisions in the CEECs become more similar to investment decisions as analyzed in our model which are characterized by high sunk costs under institutional uncertainty (Riboud et al. 2002). Hence, a main ingredient of the models of the 'option value of waiting' under (institutional) uncertainty applied in this paper is valid in the case of the CEECs. Though this might not pose many problems in the current phase of transition, besides the fact that it amplifies the impact of institutional uncertainty, it may come to the fore once the process of structural reform is completed.

\subsection{Social Union: implications for the magnitude of institutional uncertainty, of wages and of hiring and firing costs}

It might be in the interest of present EU-members to implement an EU-style institutional setup of the CEEC labor markets in the future which prevent direct wage competition with the entry countries, since the CEECs would otherwise be able to produce with significantly lower labor costs. ${ }^{8}$ However, the resulting increase of labor costs, the emergence of the 'option value of waiting with the employment decision' and the introduction of regulations and standards will strongly reduce the attractiveness of Central and Eastern Europe for FDI as well as the competitive ability of the CEECs in the Single Market. Hence, from this perspective the direct transfer of EU legislation and EU-'case law' - the acquis - onto the

8 But why will the current EU members want to impose the Social Charter even though it will harm the new members and will thus increase the possibility of a permanent dependence on financial transfer from the EU budget? Are the examples of the Mezzogiorno and of Eastern Germany with their misguided funds and wage policy not deterrent enough? Belke and Hebler (2002), pp. $325 \mathrm{ff}$., deliver a public choice analysis of why it is rational for the EU to impose the Social charter on the CEECs. 
CEECs will be likely to reduce the economic growth of Central and Eastern European economies and to increase unemployment rates.

A closer examination of previous arguments in the last paragraph reveals that they strongly remind those arguments that were brought up during the discussion on the labor market impacts of German reunification, the latter actually leading to an economic and social union between the two German states (Jovanovic 1999, p. 493). If entry of the CEECs also implies the adoption and implementation of the Social acquis by these countries, it seems justified to speak of labor market impacts of an extended social union in the context of Eastern enlargement. The flexibility of labor markets as a market co-ordination mechanism will in all probability be limited by introducing a Social Union, if the latter manifests itself in an ex ante harmonization and a centralization of social policy. The significant reduction of limitations on goods and factor markets due to the enlargement is implicitly taken back partially by an extended Social Union.

An extended European Social Union with global regulations against dismissal, (indirectly effected) harmonization of minimum wages as well as general commitment assertions towards collective wage agreements etc. have a tendency to cause additional unemployment in a first step particularly in the CEECs, which have lower social standards. At the same time labor costs tend to increase, if those employed (i.e. the 'insiders'), do not practice sufficient wage restraint or - as it became already very clear in the first phase of German reunification - a high wage policy is falsely forced onto the CEECs, in order to avoid mass emigration (Sinn 1999, p. 15; Jovanovic 1999, p. 493). The incentive for wage restraint is relatively small because of fiscal activities of the welfare state (which are anticipated by 'insiders') aiming at avoiding incentives for emigration from the CEECs ('quasi full employment warranty', public employment or income transfers without work such as unemployment benefits, social welfare assistance and regulation of early retirement) whose probability increases significantly in an extended EU. Hence, wage costs as well as hiring and firing costs should rise significantly in the CEECs.

However, the increase in wage rates and hiring and firing costs could at least partially be offset by a decrease in uncertainty about the institutional setting which by itself might foster, for instance, foreign direct investment in the CEECs. This view stands in sharp contrast to our above interpretation that the acquis represents an unsuitable set of rules for economies which find themselves no later than at the center of their 'takeoff' (Baldwin et al. 1997, p. 128). Should we weigh the latter argument more heavily? Our formal analysis will give some insights in a correct answer to this pressing question. 


\section{A model of job destruction and creation based on the option value of waiting}

\subsection{The baseline model}

The firm's employment decision can be understood as an irreversible investment. Therefore, we follow a real option approach. The following model is designed to illustrate the impacts of uncertainty according to the 'option value of waiting' à la Pindyck (1988, 1991), Dixit (1989), Dixit and Pindyck (1994), and Krugman (1989), pp. 52 ff. The firm's employment opportunity corresponds to a call option on a common stock. This option gives the firm the right to employ (invest), hiring costs being the exercise price of the option, and to obtain a 'project'. The value of this project is affected by stochastic shocks. The option itself is valuable, and exercising the employment investment "kills" the option. Therefore the loss of the option value has to be covered by future profits. Analogously, disinvestment (firing) can be interpreted as a put option (Krugman, 1989, p. 53; Pindyck, 1991, p. 1133). The same logic applies in this case.

Assume a price-taking firm which produces one unit ${ }^{9}$ of a final product, with the unit wage costs $\mathrm{w}$ being the price of labor input. Selling on the market, the firm receives the unit revenue (price) p. The interest cost of non-firm specific real capital per unit of output incurred by the firm is represented by i times K. The "gross" profit of the firm in period t (if active), without consideration of hiring and firing costs, is: ${ }^{10}$

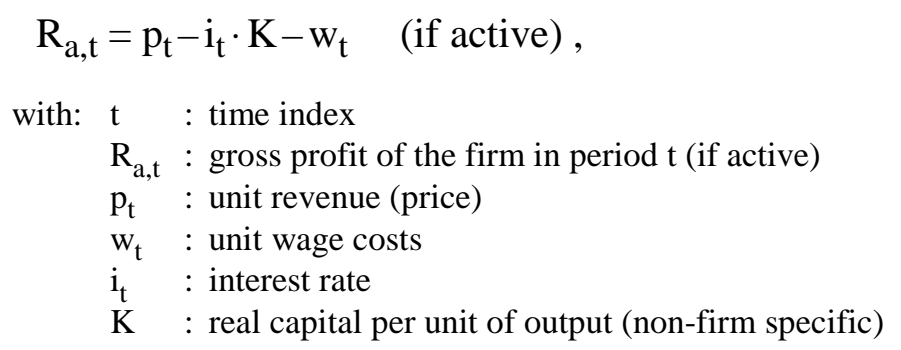

In the following we often - if not necessary for reasons of clarity - suppress the time index $t$ for reasons of parsimony.

It is assumed that some hiring costs $\mathrm{H}$ (including training costs) must be spent at the moment the entry (i.e. the job creation) is executed. ${ }^{11}$ Analogously, the firm has to pay firing costs $\mathrm{F}$ at the time it leaves the market (e.g. severance pay in the case of job destruction). If it later decides to re-enter the market, the entire hiring costs must be repaid. If the firm is inactive for

9 By this, we follow a very general approach: Imagine an institutional firm as divided into single production units, so that every unit is represented individually. We do not restrict the structure of the costs between these units. Moreover, via this fictitious disaggregation our calculation can represent a totally new erection as well as an enlargement of employment by an institutional firm.

10 See Belke and Göcke (1994) for a related model of labor demand. Here the reaction of only a single firm is analyzed. However, for aggregation the heterogeneity effects are especially important (see Belke and Göcke 1998). For empirical evidence of heterogeneity for Italian manufacturing firms see Guiso and Parigi (1997).

11 Investment in employment that takes 'time to build' does even magnify the effect of uncertainty (see Pindyck 1988, p. 973; Dixit and Pindyck 1994, pp. 46 ff). 
only one period, the staff must be completely re-set up and the hiring costs must be paid anew. Specific investments in new employees close to the production process may partly be irreversible because of market regulation and institutional arrangements. ${ }^{12}$ In our model switching the state of activity leads to a complete depreciation of hiring respectively firing costs. ${ }^{13}$ Thus $\mathrm{H}$ and $\mathrm{F}$ have to be regarded as sunk costs ex post (Dixit and Pindyck 1994, p. 8; Bentolila and Bertola 1990; Dornbusch 1987, pp. 7 ff.).

\subsection{One-off uncertainty and the possibility of waiting}

\subsubsection{The implication of uncertainty and the option value of waiting}

In order to demonstrate the effects of uncertainty and of the "option to wait" on job creation and destruction we have to introduce uncertainty in our model. Focusing on employment impacts of uncertainty, we take up an idea originally proposed by Dornbusch (1987), pp. $8 \mathrm{f}$., Dixit (1989), p.624, fn.3, and Pindyck (1991), p.1111. In order reveal the underlying economics we prefer simple instead of advanced dynamic programming tools. Thus, as a simplification, we explicitly model only a one-time stochastic shock as a generator of the option value of waiting. Modeling ongoing uncertainty would be more realistic, however, the qualitative effects of uncertainty on hiring and firing triggers would not change (but the quantitative impact of uncertainty would even be amplified compared to our result). ${ }^{14}$

The future gross profit of the firm is now regarded as stochastic. For simplicity reasons, we abstract from additional uncertainty over $\mathrm{H}$ and $\mathrm{F}$. We suppose a non-recurring single stochastic change in the profit $R$, which can be either positive $(+u)$ or negative $(-u)$ (with $\mathrm{u} \geq 0$, mean preserving spread). ${ }^{15}$ For simplicity reasons, both realizations of the shock do have the same probability of $1 / 2$ :

$$
\mathrm{R}_{\mathrm{a}, \mathrm{t}+1}=\mathrm{R}_{\mathrm{a}, \mathrm{t}} \pm \mathrm{u} \Rightarrow \mathrm{E}_{\mathrm{t}}\left(\mathrm{R}_{\mathrm{a}, \mathrm{t}+1}\right)=\mathrm{R}_{\mathrm{a}, \mathrm{t}}
$$

Without the option to wait with the hiring/firing decision, the relevant alternative strategies are to enter/hire or not for a previously inactive firm respectively to exit/fire or not for a formerly active firm. Under uncertainty and the feasibility to delay, the option to wait and to make the respective decision (i.e. entry or exit) in the future has to be taken into account as a third alternative. The option to hire in the future (and not now-or-never) is valuable because the future value of the 'asset' obtained by employment project is uncertain. If its value will

12 In this paper a specific investment is analyzed. However, one has to distinguish general investment, which enables the firm to cope with different future situations. Thus the latter type may be positively correlated with uncertainty (see e.g. Gros 1987).

13 A firm may have the option to produce or not to produce with an existing "project" (operating option, Pindyck 1988, p. 970, p. 982). Our firm does not dispose of this option, since already one period of inaction leads to complete depreciation of the "employment project".

14 Explicitly modeling only a single stochastic shock (instead of permanent uncertainty) results in the applicability of very simple algebraic methods instead of using dynamic programming techniques as described by Dixit and Pindyck (1994), pp. 95 ff.

15 This kind of binomial stochastic process was introduced into option pricing by Cox et al. (1979). 
decrease, the firm will not need to enter. This limits the risk downwards and thus generates the inherent value of the option (Dixit and Pindyck 1994, p. 9 and pp. 15 ff.; Krugman 1989, p. 53).

The stochastic shock " $u$ " comprises all components of uncertainty one could think of as relevant for the gross profits $\mathrm{R}$ of the firms. These components can be traced back directly to (unexpected) movements of the price, of labor and capital costs and also indirectly to the still indetermined institutional environment. ${ }^{16}$ In practice, uncertainty inherent in the institutional environment means uncertainty with respect to future profits. Hence, institutional uncertainty induces uncertainty about future returns and is approximated by the latter in our model. Following this line of reasoning, a more certain institutional environment implies lower institutional uncertainty and, thus, a smaller absolute realization of \pm , i.e., of the "comprehensive uncertainty measure".

\subsubsection{Potential job creation: unemployed (i.e. passive) in the preceding period}

A previously inactive firm has to decide whether to create a job now (instantaneous entry) or to stay passive, including the option to hire later. It may be advantageous for the firm to dispense with transient period $t$ gains, if future losses are possible, since the firm can avoid the danger of an "overhasty" entry - which later may turn out to be the wrong decision - via a wait-and-see-strategy. The firm preserves the possibility of internalizing future gains by the option to enter in the next period $\mathrm{t}+1$ if the future profit opportunities will turn out to be favorable $(+u)$. Moreover, by further staying passive the firm can avoid future losses if the profit change will be negative $(-u)$. In the following, we abstract from the possibility to re-exit (for this see Belke and Göcke 1999, the results do not change qualitatively). Moreover, we assume instantaneous entry if conditions are favorable.

A firm which currently enters the market and will continue its activity will gain the period t "gross" profit $\mathrm{R}_{\mathrm{a}, \mathrm{t}}$. Since it expects the same profit for the whole infinite future the present value of annuity due of future profits under activity from period $t+1$ on is $\delta \cdot \mathrm{V}_{\mathrm{a}, \mathrm{t}+1}=\delta \cdot(\mathrm{p}-\mathrm{i} \cdot \mathrm{K}-\mathrm{w}) /(1-\delta)$. The discount factor is defined as $\delta \equiv 1 /(1+\mathrm{i})$ with a risk free interest rate i; i.e. $(1-\delta)=\delta \cdot i$ is the rate of interest costs. The entire expected net present value of an instantaneous entry is:

16 I.e. the "comprehensive" variation described by the stochastic change u comprises all the expected effects of changes of the price level and of unit labor and capital costs on the variation of the expected unit profit (which is calculated as the difference of the former). 


$$
\mathrm{E}_{\mathrm{t}}\left(\mathrm{V}_{\mathrm{t}}^{\mathrm{entry}}\right)=-\mathrm{H}+\mathrm{R}_{\mathrm{a}, \mathrm{t}}+\delta \cdot \mathrm{V}_{\mathrm{a}, \mathrm{t}+1}=-\mathrm{H}+\frac{\mathrm{p}-\mathrm{i} \cdot \mathrm{K}-\mathrm{W}}{1-\delta}
$$

with: $E_{t}\left(R_{a, t+1}\right)=R_{a, t}=p-i \cdot K-w$

$$
\begin{aligned}
& \mathrm{H} \quad \text { : sunk hiring / investment costs } \\
& \left.\delta \equiv \frac{1}{1+\mathrm{i}}: \text { discount factor } \Leftrightarrow \mathrm{i}=\frac{1-\delta}{\delta} \Leftrightarrow(1-\delta)=\delta \cdot \mathrm{i}=\frac{\mathrm{i}}{1+\mathrm{i}} \quad \text { (with: } \mathrm{i}>0 \Leftrightarrow \delta<1\right) \\
& \mathrm{V}_{\mathrm{a}, \mathrm{t}+1} \quad \text { : present value of annuity due in period } \mathrm{t}+1 \text { of future revenues of an active firm }
\end{aligned}
$$

The expected present value of a waiting in period $t$ is defined as the probability weighted average of the present values of both stochastic u-realizations. In the case of a $(+u)-$ realization, the firm will use its option to hire in the future period $t+1$ causing sunk costs $\mathrm{H}$, and the present value is:

$$
\mathrm{R}_{\mathrm{p}, \mathrm{t}}-\delta \cdot \mathrm{H}+\delta \cdot \mathrm{V}_{\mathrm{a}, \mathrm{t}+1}=0-\delta \cdot \mathrm{H}+\delta \cdot \frac{\mathrm{p}+\mathrm{u}-\mathrm{i} \cdot \mathrm{K}-\mathrm{w}}{1-\delta}
$$

Conditional on a $(-\mathrm{u})$-realization the firm will continue to stay passive: $\mathrm{R}_{\mathrm{p}, \mathrm{t}}+\delta \cdot \mathrm{V}_{\mathrm{p}, \mathrm{t}+1}=0+\delta \cdot 0=0$. Consequently, the expected net present value of a wait-and-see strategy of a firm which is previously inactive is:

$$
\mathrm{E}_{\mathrm{t}}\left(\mathrm{V}_{\mathrm{t}}^{\mathrm{wait}}\right)=-\frac{1}{2} \cdot \delta \cdot \mathrm{H}+\frac{1}{2} \cdot \delta \cdot \frac{\mathrm{p}+\mathrm{u}-\mathrm{i} \cdot \mathrm{K}-\mathrm{w}}{1-\delta}
$$

The value of possessing the flexibility to make the employment decision later rather than to employ either now or never, can be calculated as the difference between the two expected net present values:

$$
\mathrm{OV}\left(\mathrm{p}_{\mathrm{t}}, \mathrm{u}\right)=\mathrm{E}_{\mathrm{t}}\left(\mathrm{V}_{\mathrm{t}}^{\text {wait }}\right)-\mathrm{E}_{\mathrm{t}}\left(\mathrm{V}_{\mathrm{t}}^{\text {entry }}\right)
$$$$
\text { with: } \frac{\partial \mathrm{OV}}{\partial \mathrm{p}_{\mathrm{t}}}<0, \frac{\partial \mathrm{OV}}{\partial \mathrm{u}}>0
$$

An increase in the size of uncertainty $u$ enlarges the value of the option to employ later. A higher size of the shock enlarges the potential payoff of the option, leaving the downside payoff unchanged, since the firm will not exercise the hiring option if the profit falls (Dixit and Pindyck 1994, pp. 39 f.).

The firm is indifferent between both, instantaneous entry in the current period t or a wait-andsee strategy, if $E_{t}\left(V_{t}^{\text {entry }}\right)=E_{t}\left(V_{t}^{\text {wait }}\right)$, i.e. if $O V=0$. The entry-trigger price follows (entry for $\left.\mathrm{p}_{\mathrm{t}}>\mathrm{p}_{\text {entry }}^{\mathrm{u}}\right)$ :

$$
\mathrm{p}_{\text {entry }}^{\mathrm{u}}=\frac{1-\delta}{\delta} \cdot \mathrm{K}+\mathrm{w}+(1-\delta) \cdot \mathrm{H}+\frac{\delta \cdot \mathrm{u}}{2-\delta}=\mathrm{i} \cdot \mathrm{K}+\mathrm{w}+\frac{\mathrm{i}}{1+\mathrm{i}} \cdot \mathrm{H}+\frac{\mathrm{u}}{1+2 \mathrm{i}}
$$

Note that, on the one hand, the "variable" and non-sunk unit costs correspond to the interest costs on the non-firm specific real capital stock $\mathrm{K}$ and to the wage costs $\mathrm{w}$. On the other hand, the interest costs on sunk costs $(1-\delta) \cdot \mathrm{H}$ and the coverage of the option value of waiting $\frac{\mathrm{u}}{1+2 \mathrm{i}}$ becomes relevant. The central result here is that the entry trigger exceeds the "variable" 
unit costs, since additionally the sunk costs and the option value of waiting have to be covered by the unit revenue.

Simplifying, assuming the absence of interest rate changes $(\mathrm{di}=0)$ and of changes in the capital input $(\mathrm{dK}=0)$, the total differential with respect to the indifference-/trigger-condition in eq. (7) can be calculated as follows: ${ }^{17}$

$$
\mathrm{dp}_{\mathrm{entry}}^{\mathrm{u}}=\mathrm{dw}+\frac{\mathrm{i}}{1+\mathrm{i}} \cdot \mathrm{dH}+\frac{\mathrm{du}}{1+2 \mathrm{i}} \text {. }
$$

From this indifference/trigger condition based on eq. (7) we can derive some expressions for a bilateral compensation of the effects of changes of in each case two variables (similar to a kind of "marginal rate of substitution"). Indifference between instantaneous hiring and waiting is always maintained, since both effects cancel out in each case:

$$
\begin{aligned}
& \frac{\mathrm{dp}_{\text {entry }}^{\mathrm{u}}}{\mathrm{dH}}=1-\delta=\frac{\mathrm{i}}{1+\mathrm{i}} \quad ; \quad \frac{\mathrm{dp}_{\text {entry }}^{\mathrm{u}}}{\mathrm{du}}=\frac{\mathrm{dw}_{(\text {entry })}}{-\mathrm{du}}=\frac{\delta}{2-\delta}=\frac{1}{1+2 \mathrm{i}} \quad ; \quad \frac{\mathrm{dp} \mathrm{entry}^{\mathrm{u}}}{\mathrm{dw}}=1 \\
& \frac{\mathrm{dH}}{\mathrm{du}}=\frac{-\delta}{(1-\delta) \cdot(2-\delta)}=\frac{-(1+\mathrm{i})}{\mathrm{i} \cdot(1+2 \mathrm{i})} \quad ; \quad \frac{\mathrm{dH}}{\mathrm{dw}}=\frac{-\mathrm{dH}}{\mathrm{d} p_{\text {entry }}^{\mathrm{u}}}=\frac{-1}{1-\delta}=\frac{-(1+\mathrm{i})}{\mathrm{i}}
\end{aligned}
$$

\subsubsection{Potential job destruction: employed (i.e. active) in the preceding period}

In the exit (i.e. firing and job destruction) case we abstract from the possibility to re-entry (for this see Belke and Göcke 1999). If a previously active firm exits and fires its staff in the current period $t$, it has to bear sunk firing or disinvestment costs $\mathrm{F}$. As a result the firm will get zero current and future gains $\left(\mathrm{R}_{\mathrm{p}, \mathrm{t}}=0\right.$ and $\left.\mathrm{V}_{\mathrm{p}, \mathrm{t}+1}=0\right)$ and therefore the present value of an instantaneous exit can be written as:

$$
\mathrm{R}_{\mathrm{p}, \mathrm{t}}+\delta \cdot \mathrm{V}_{\mathrm{p}, \mathrm{t}+1}-\mathrm{F}=-\mathrm{F}
$$

In an uncertain environment a previously active firm has to decide whether to leave the market now (instantaneous exit) or to stay active, including the option to leave later. It may be advantageous for the firm to bear temporary losses in the current period, if there is a chance of future gains. In this case the active firm can avoid superfluous exit and re-entry costs. On the one hand the firm takes into account the possibility of future gains if the future profit will turn out to be favorable $(+u)$. On the other hand, in the case of a negative profit change $(-u)$ the firm can avoid future losses via a future exit in $\mathrm{t}+1$.

17 In this paper we only analyze the effects of a social union on the hiring and firing decisions in the new member countries. Further effects of the general process of European integration are not included. E.g., the integration of capital markets and the better access to European capital markets by CEEC firms may result in a reduction of unit capital costs $(\mathrm{di}<0)$. The reduction of European trade barriers and the cancellation of tariffs due to the Single European market may result in a higher unit revenues of the CEEC firms $(\mathrm{dp}>0)$. Hence, these further effects of European integration are expected to increase the (expected) profits and with this will have a positive effect on job creation and a negative one on job destruction. 
The expected present value of a waiting strategy is defined as the probability-weighted average of the present values of both u-realizations. Conditional on the negative $(-\mathrm{u})$ realization the firm will use its option to fire in $\mathrm{t}+1$ causing sunk costs $\mathrm{F}$ and the present value is:

$$
\mathrm{R}_{\mathrm{a}, \mathrm{t}}-\delta \cdot \mathrm{F}+\delta \cdot \mathrm{V}_{\mathrm{p}, \mathrm{t}+1}=\mathrm{p}-\frac{1-\delta}{\delta} \cdot \mathrm{K}-\mathrm{w}-\delta \cdot \mathrm{F}
$$

In the case of a favorable $(+\mathrm{u})$-realization the firm will continue its activity:

$$
\mathrm{R}_{\mathrm{a}, \mathrm{t}}+\delta \cdot \mathrm{V}_{\mathrm{a}, \mathrm{t}+1}=\mathrm{p}-\frac{1-\delta}{\delta} \cdot \mathrm{K}-\mathrm{w}+\delta \cdot \frac{\mathrm{p}+\mathrm{u}-\frac{1-\delta}{\delta} \cdot \mathrm{K}-\mathrm{w}}{1-\delta}
$$

Combining (11) and (12) with probability $1 / 2$ each, the expected present value of a wait-andsee strategy is:

$$
\mathrm{E}_{\mathrm{t}}\left(\mathrm{V}_{\mathrm{t}}^{\mathrm{wait}}\right)=\mathrm{p}-\frac{1-\delta}{\delta} \cdot \mathrm{K}-\mathrm{w}-\frac{1}{2} \cdot \delta \cdot \mathrm{F}+\frac{1}{2} \cdot \delta \cdot \frac{\mathrm{p}+\mathrm{u}-\frac{1-\delta}{\delta} \cdot \mathrm{K}-\mathrm{w}}{1-\delta}
$$

The present value of an immediate exit is simply given by sunk firing costs F:

$$
\mathrm{E}_{\mathrm{t}}\left(\mathrm{V}_{\mathrm{t}}^{\text {exit }}\right)=\mathrm{V}_{\mathrm{t}}^{\text {exit }}=-\mathrm{F}
$$

Hence, the firm is indifferent between an exit in $t$ and 'wait-and-see' if $\mathrm{E}_{\mathrm{t}}\left(\mathrm{V}_{\mathrm{t}}^{\text {exit }}\right)=\mathrm{E}_{\mathrm{t}}\left(\mathrm{V}_{\mathrm{t}}^{\text {wait }}\right)$. Consequently, the unit revenue that triggers immediate firing follows (with: exit for $p_{t}<p_{\text {exit }}^{u}$ ):

$$
\mathrm{p}_{\text {exit }}^{\mathrm{u}}=\frac{1-\delta}{\delta} \cdot \mathrm{K}+\mathrm{w}-(1-\delta) \cdot \mathrm{F}-\frac{\delta \cdot \mathrm{u}}{2-\delta}=\mathrm{i} \cdot \mathrm{K}+\mathrm{w}-\frac{\mathrm{i}}{1+\mathrm{i}} \cdot \mathrm{F}-\frac{\mathrm{u}}{1+2 \mathrm{i}}
$$

Assuming (ceteris paribus) the absence of changes of the interest rate $(\mathrm{di}=0)$ and of the capital input $(\mathrm{dK}=0)$, the total differential with respect to the indifference-/trigger-condition in eq. (15) can be written as follows:

$$
\mathrm{dp}_{\mathrm{exit}}^{\mathrm{u}}=\mathrm{dw}-\frac{\mathrm{i}}{1+\mathrm{i}} \cdot \mathrm{dF}-\frac{\mathrm{du}}{1+2 \mathrm{i}}
$$

From this indifference/trigger condition based on eq. (16) we can derive some expressions for the bilateral compensation of the effects of changes of in each case two variables. Indifference is again always maintained, since both effects cancel out in each case:

$$
\begin{aligned}
& \frac{\mathrm{dp}_{\text {exit }}^{\mathrm{u}}}{\mathrm{dF}}=-(1-\delta)=\frac{-\mathrm{i}}{1+\mathrm{i}} ; \quad \frac{\mathrm{dp}_{\text {exit }}^{\mathrm{u}}}{\mathrm{du}}=\frac{\mathrm{dw}_{(\text {exit })}}{-\mathrm{du}}=\frac{-\delta}{2-\delta}=\frac{-1}{1+2 \mathrm{i}} ; \quad \frac{\mathrm{dp} \mathrm{exit}_{\mathrm{e}}^{\mathrm{u}}}{\mathrm{dw}}=1 \\
& \frac{\mathrm{dF}}{\mathrm{du}}=\frac{-\delta}{(1-\delta) \cdot(2-\delta)}=\frac{-(1+\mathrm{i})}{\mathrm{i} \cdot(1+2 \mathrm{i})} ; \quad \frac{\mathrm{dF}}{\mathrm{dw}}=\frac{-\mathrm{dF}}{\mathrm{dp}_{\text {exit }}^{\mathrm{u}}}=\frac{1}{1-\delta}=\frac{1+\mathrm{i}}{\mathrm{i}}
\end{aligned}
$$




\subsection{Position and width of the 'band of inaction' under uncertainty}

Due to the sunk hiring costs $\mathrm{H}$, the unit revenue which is sufficient to induce an entry is larger than the variable costs. And due to sunk firing costs $\mathrm{F}$ only a price sufficiently below the variable costs leads to an exit. Combining both trigger values, a 'band of inaction' results (see Fig. 1). The latter implies that the current realization of the unit revenue $\mathrm{p}_{\mathrm{t}}$ is not sufficient to determine the current state of the firm's activity. Depending on the past state of activity, the relationship between profit or price and present state of activity is represented by different curves. In order to select one of the multiple equilibria, the history has to be regarded; i.e. we have a situation with hysteresis.

Under uncertainty the entry (exit) trigger price is additively (subtractively) augmented by the term $\frac{\mathrm{du}}{1+2 \mathrm{i}}$. Thus, via option value effects of waiting, uncertainty leads to an expansion of the 'band of inaction'. Uncertainty increases the probability that a firm stays active (passive) if the current level of the profit has descended (ascended) from a formerly high (low) level that in the past had induced an entry (exit). In our oversimplified model the expansion of the 'band of inaction' is even linear and separable with respect to the anticipated absolute size u of the shock. Furthermore, in this simple set up the expansion is even independent of any aspects of heterogeneity concerning the variable and the sunk costs of the firm. ${ }^{18}$

\section{Fig. 1: Effects of sunk costs and uncertainty on employment: the 'band of inaction'}

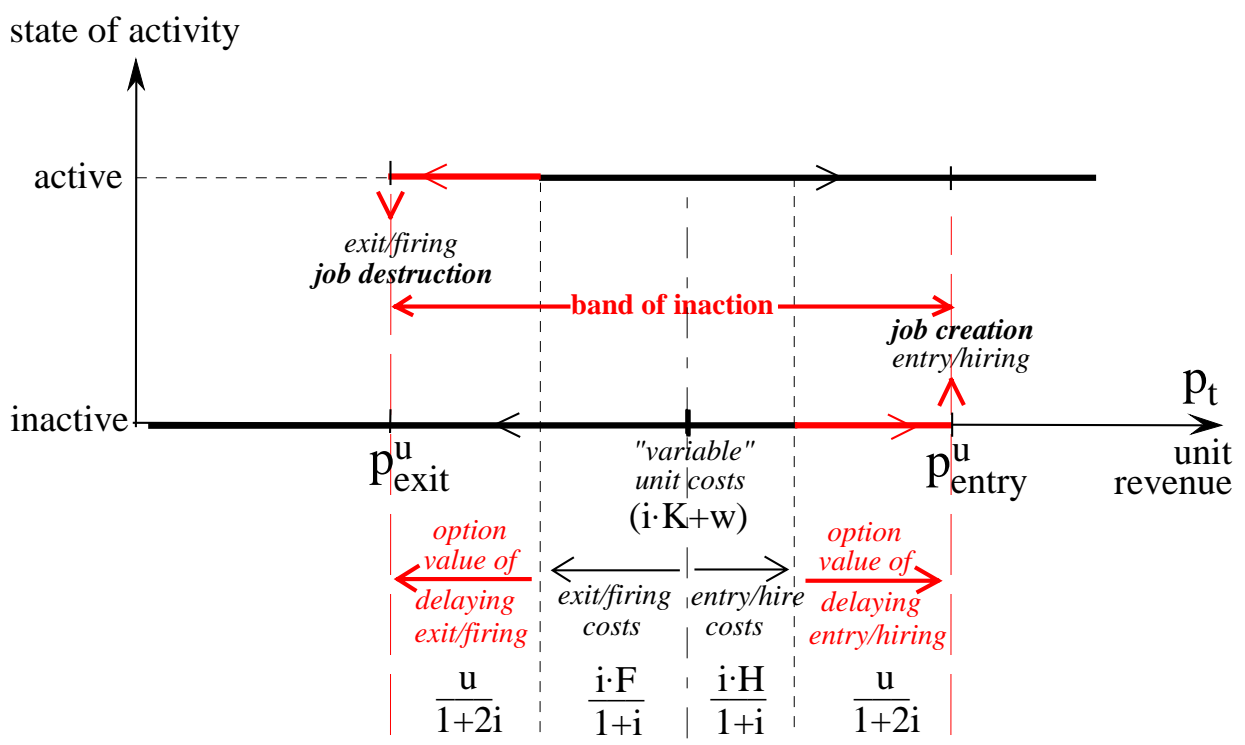

18 Of course, these simple mathematical characteristics are a result of our simplifying assumptions, concerning the inclusion of a re-entry or re-exit and of explicitly only analyzing a one-off stochastic shock. In a more general setting, the direction of the option value effect would remain, however the impact of uncertainty on the 'band of inaction' would not be linear-separable. 


\section{Scenario of EU Eastern enlargement: impacts on job creation and job destruction}

In order to derive the impacts of Eastern Enlargement and the adoption of a European Social Union on job creation and destruction in the CEECs, we have to take into account and to weight against each other the following direct implications of the change in the institutional framework.

- $\mathrm{dH}, \mathrm{dF}>0$, i.e., an increase of hiring and firing costs due to the adoption of social and labor market policy institutions of the acquis. In section 2 , we argued that directives and regulations of the acquis can be seen as the attempt of some of the established EU-countries to export labor market rigidities, i.e. significant hiring and firing costs and also higher minimum wages, to poorer and 'catching up' economies which originally offered a more competitive production environment because of lower labor costs and lower standards.

- $d w>0$, i.e., increasing wages due to, e.g., higher unionization, harmonization of minimum wages, general commitment assertions towards collective wage agreements and a higher reservation wage due to an extended welfare state as well as higher taxes on labor (in order to finance the welfare state).

- $d u<0$, i.e., a negative effect of diminished institutional uncertainty on the variation of expected profits due to the adoption of the acquis. Note that in section 2 we argued that the CEECs urgently need market economy rules in order to remove the prevailing legal uncertainty which currently restrains investment. Hence, the transfer of a set of rules such as the acquis might be interpreted as a reliable obligation to the transformation process. This was defined by us as the elimination of institutional uncertainty.

While $\mathrm{dH}>0$ leads to less job creation, $\mathrm{dF}>0$ hampers job destruction. The reduction in institutional uncertainty $\mathrm{du}<0$ tends to lead to more job creation and more job destruction simultaneously. It cannot be determined a priori which effect dominates. However, the increase of wages $d w>0$ causes less job creation and more job destruction. In other words, four out of six primary impacts tend to have a negative impact on labor market performance in the CEECs. These relationships are summarized graphically in Fig. 2. 
Fig. 2: Three selected effects of EU Eastern enlargement on price triggers and on the position of the 'band of inaction' in CEEC employment

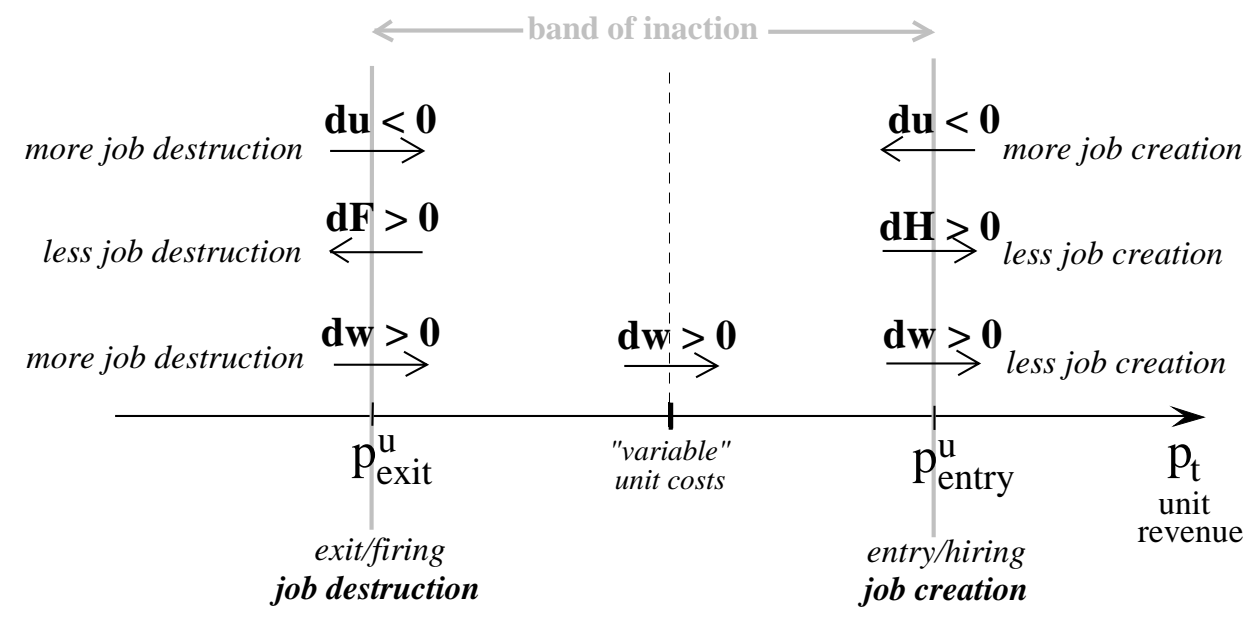

Given the trigger conditions in eqs. (8) and (16), we can derive conditions under which the total effect of enlargement on job creation and destruction in the CEECs is unambiguous.

Job-creation is fostered insofar as the hire trigger value of the unit revenue in eq. (8) is lowered after accounting for all partial impacts $\left(\mathrm{dp}_{\mathrm{entry}}^{\mathrm{u}}<0\right)$ :

$$
d p_{\text {entry }}^{\mathrm{u}}<0 \Leftrightarrow \mathrm{dw}+\frac{\mathrm{i}}{1+\mathrm{i}} \cdot \mathrm{dH}<\frac{-\mathrm{du}}{1+2 \mathrm{i}}
$$

The stronger the increase of wages is and the higher the interest costs of the sunk hiring costs become, the lower the number of jobs created. The more institutional uncertainty is eliminated, the higher the rate of job creation.

However, job-destruction is promoted exactly if enlargement results in an increase of the fire trigger value in eq. (16) $\left(\mathrm{dp}_{\text {exit }}^{\mathrm{u}}>0\right)$ :

$$
\mathrm{dp}_{\text {exit }}^{\mathrm{u}}>0 \Leftrightarrow \mathrm{dw}+\frac{-\mathrm{du}}{1+2 \mathrm{i}}>\frac{\mathrm{i}}{1+\mathrm{i}} \cdot \mathrm{dF}
$$

The stronger the increase of wages and the more institutional uncertainty shrinks, the more jobs are eliminated. However, the higher the firing costs become, the less probable is job destruction.

Summarizing, a reduction of uncertainty by the adoption of a well-tried and tested institutional framework, i.e. of the acquis, on the one hand fosters structural change since it leads at the same time to more job-creation and more job-destruction. However, one has to work on the assumption that rigidities increase, for instance by an increase of the (sunk) costs $\mathrm{H}$ and $\mathrm{F}$. Ceteris paribus, the latter leads to a widening of the 'band of inaction' and, thus, preserves given structures. However, it cannot be determined a priori which effect dominates. The higher the interest rates are, the more probable is a bias towards the status-quo - 
according to our simple model. The probable increase of the wage costs effects an upward movement of the band of inaction. This means an amplification of job-destruction, but at the same time a mitigation of job-creation. Moreover, it once again elucidates the danger of a "Mezzogiorno" respectively of a "German unification" effect, i.e. a strong decline of jobs and high unemployment induced by excessive wage costs. ${ }^{19}$

\section{Simulation exercises: Graphical illustration of the trade-offs}

In order to convey an idea of the impacts of the underlying model and to illustrate our results, we calculate a simple numerical example. The unit labor costs are normalized to unity $(\mathrm{w}=1)$ and as a standard example we take the short-term interest rate given as $i=0.1=10 \%$.

In the case of the following initial values, we are able to calculate the trigger prices from eqs. (7) and (15) and the bilateral trade-offs corresponding to eqs. (9) and (17):

- non-specific real capital: $\mathrm{K}=5$

- absolute size of uncertainty: $\mathrm{u}=0.2$

- sunk hire/fire costs: $\mathrm{H}=\mathrm{F}=1$

- non-specific real capital: $K=5$

$\Rightarrow \quad \mathrm{p}_{\text {entry }}^{\mathrm{u}}=1.757575, \mathrm{p}_{\text {exit }}^{\mathrm{u}}=1.242424$

$\Rightarrow \quad$ width of the 'band of inaction': $p_{\text {entry }}^{\mathrm{u}}-\mathrm{p}_{\text {exit }}^{\mathrm{u}}=0.515151$

$\Rightarrow \frac{d H}{d u}=\frac{d F}{d u}=-9.166666 ; \frac{d p_{\text {entry }}^{u}}{d u}=\frac{\left.-d w_{(e n t r y)}\right)}{d u}=\frac{-d p_{\text {exit }}^{u}}{d u}=\frac{d w_{(e x i t)}}{d u}=0.833333$

$$
\frac{d p_{\text {entry }}^{\mathrm{u}}}{\mathrm{dH}}=\frac{-\mathrm{dH}}{\mathrm{dw}}=\frac{-\mathrm{dp}_{\mathrm{exit}}^{\mathrm{u}}}{\mathrm{dF}}=\frac{\mathrm{dF}}{\mathrm{dw}}=0.090909
$$

19 As stated in fn. 17, a European integration of capital markets may lead to lower interest rates in the CEEC. This would have two further effects on the 'band of inaction'. The reduction of unit capital costs will result in a leftward shift of the center of the band (i.e. more job creation and less job destruction). Since sunk (dis)investments are incorporated into the firm's calculus via their interest costs, a reduction of the interest rate will lead to a decreasing width of the band on both sides (i.e. structural change is fostered via more job creation and more job destruction). Thus, integration of capital markets may (partly) compensate the effects of the social union outlined above and thus will reduce the danger of a "Mezzogiorno / Eastern Germany" scenario. 


$$
-19-
$$

Fig. 3: "Partial indifference trade-off" on job creation between a change of hiring costs $(\mathrm{dH})$ and the reduction of uncertainty $(-d u)$ dependent on different realizations of the interest rate

$$
\begin{aligned}
& \text { (if } \left.d w=d p_{\text {entry }}^{u}=0\right) \\
& \frac{\mathrm{dH}}{\mathrm{du}}=\frac{-(1+\mathrm{i})}{\mathrm{i} \cdot(1+2 \mathrm{i})}
\end{aligned}
$$

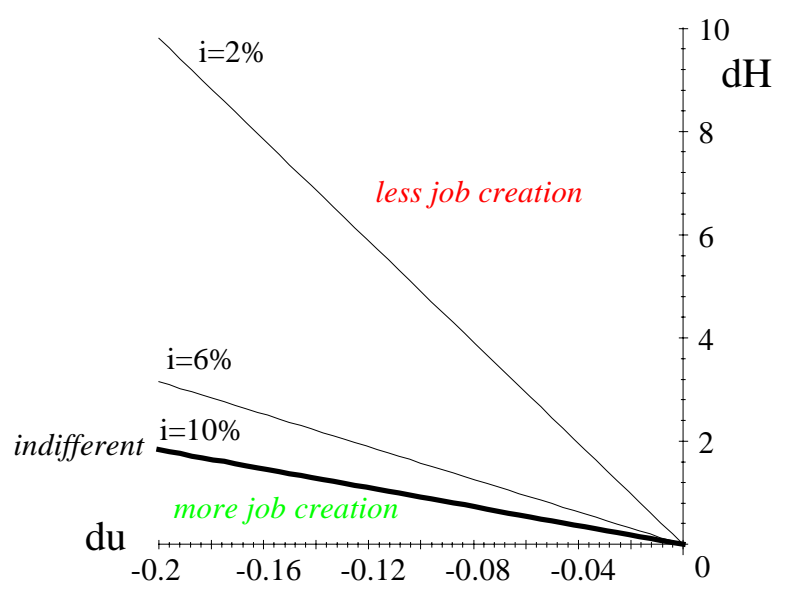

The comments on Fig. 3 are quite straightforward. Above the indifference line, the increase of sunk hiring costs $\mathrm{dH}$ has a stronger impact than reduction of uncertainty (-du). Hence job created is impeded in this area. Below the indifference line the reduction of uncertainty dominates and job creation is fostered in this area. As a consequence, a higher interest rate tends to lower job creation.

Fig. 4: "Partial indifference trade-off" on job destruction between a change of firing costs $(d F)$ and the reduction of uncertainty $(-d u)$

$$
\text { (if } \left.d w=d p_{\text {exit }}^{u}=0\right) \quad \frac{\mathrm{dF}}{\mathrm{du}}=\frac{-(1+\mathrm{i})}{\mathrm{i} \cdot(1+2 \mathrm{i})}
$$

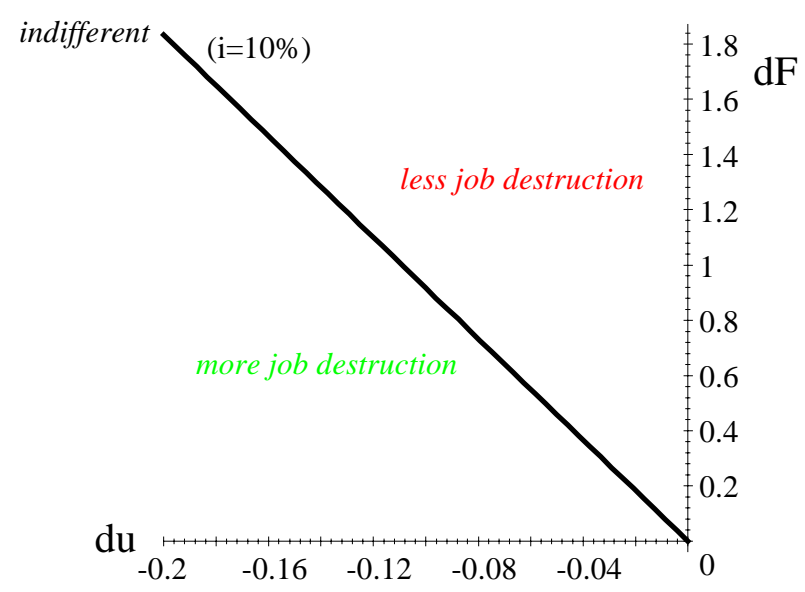


The comments on Fig. 4 are analogous to the comments on Fig. 3. Above the indifference line, the increase of sunk firing costs $\mathrm{dF}$ has a stronger impact than the reduction of uncertainty $(-\mathrm{du})$. Hence job destruction is impeded in this area. Below the indifference line the reduction of uncertainty dominates and job destruction is fostered in this area.

Note that the reduction of uncertainty fosters structural change by at the same time supporting job creation and job destruction. The net effect on total economy labor demand is ambiguous a priori, since these two effects are counteracting each other. Moreover, the interest rate is quite important for the trade-off, since sunk investments are incorporated into the firm's calculus via their interest costs.

Fig. 5: "Partial indifference trade-off" on job creation between a change in unit labor costs $(d w)$ and the reduction of uncertainty (-du) dependent on different realizations of the interest rate

$$
\text { (if } \left.d H=d p_{\text {entry }}^{u}=0\right) \quad \frac{\mathrm{dw}_{(\mathrm{exit})}}{\mathrm{du}}=\frac{-1}{1+2 \mathrm{i}}
$$

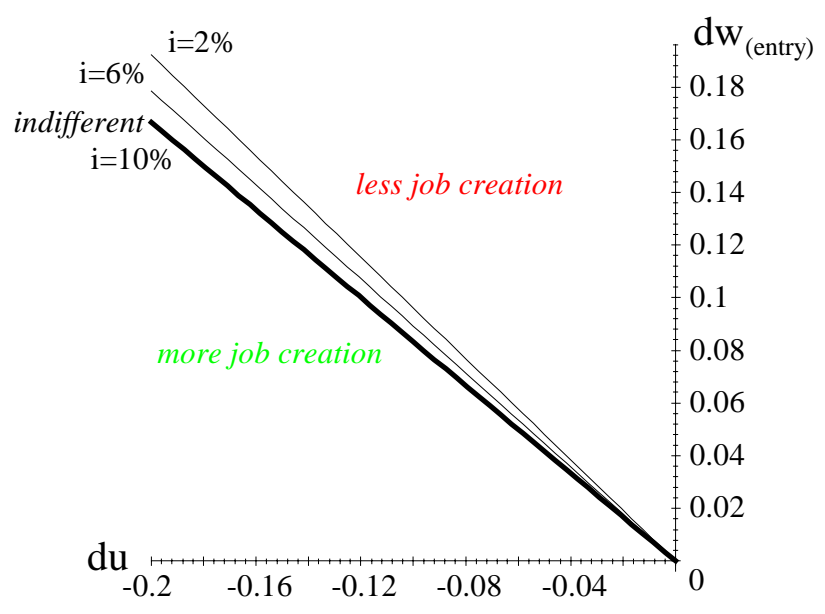

Comment on Fig. 5: the negative impact of the wage increase on the degree of job creation can be compensated by a reduction of the option value of waiting in the wake of the lowering of uncertainty. The higher the reduction of uncertainty is, the more job creation takes place. 
Fig. 6: "Partial indifference trade-off" on job destruction between the change in unit labor costs $(d w)$ and the reduction of uncertainty $(-d u)$

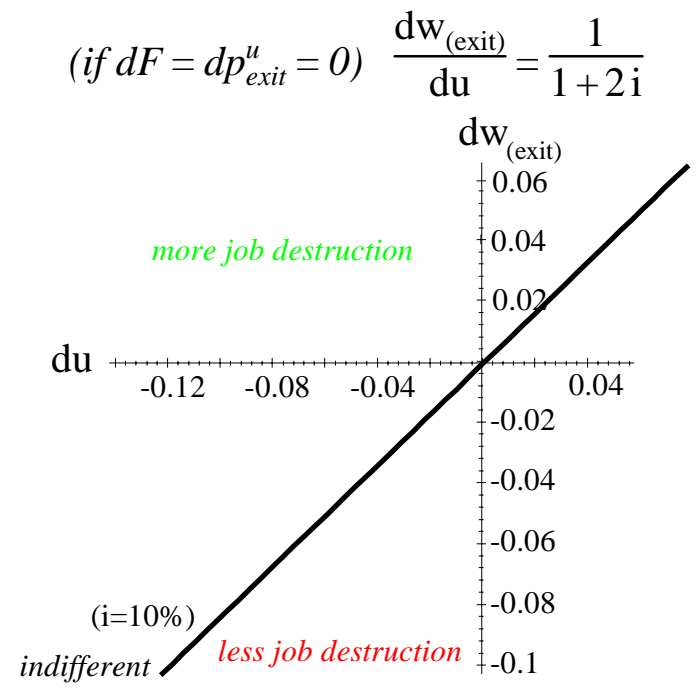

Comment on Fig. 6: If unit labor costs increase $(\mathrm{dw}>0)$ this fosters job destruction. This effect could be compensated by a increase in uncertainty. However, since according to section 2, an increase of unit labor costs in the CEECs is a highly probable scenario, more job destruction should be observed in the CEECs after enlargement. Thus we predict a situation in the north-western quadrant of Fig. 6 where job destruction is boosted.

Fig. 7: "Three-dimensional indifference trade-off” for the entry/hiring trigger condition between the change in unit labor costs $(d w)$, the reduction of uncertainty $(-d u)$ and the change of the sunk hiring costs $(\mathrm{dH})$

$$
\begin{gathered}
\mathrm{dp}_{\mathrm{entry}}^{\mathrm{u}}=0 \Leftrightarrow \mathrm{dw}=\frac{-\mathrm{du}}{1+2 \mathrm{i}}-\frac{\mathrm{i}}{1+\mathrm{i}} \cdot \mathrm{dH} \\
(\text { for } i=10 \%: d w=-0.833333 d u-0.090909 d \mathrm{~d})
\end{gathered}
$$

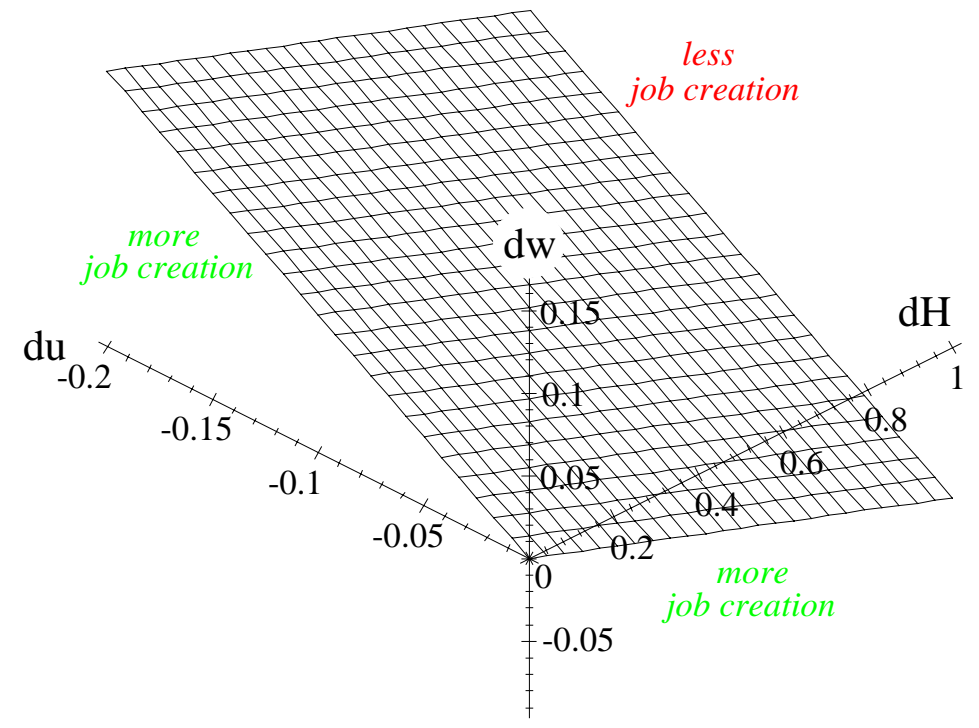

Comment on Fig. 7: Below the depicted "indifference plane", the $\mathrm{p}_{\mathrm{u} \text { try }}^{\mathrm{u}}$-trigger is lowered. Hence, hiring increases in this area. However and with the same logic, hiring diminishes for any point above the indifference plane. Since we forecast a reduction of uncertainty and at the 
same time an increase of the (sunk) hiring and firing costs alongside with wage increases, it cannot be said a priori whether the case of the CEECs after the adoption of the acquis corresponds to a location below or above the indifference area.

Fig. 8: "Three-dimensional indifference trade-off" for the exit/firing trigger condition between the change in unit labor costs $(d w)$, the reduction of uncertainty $(-d u)$ and the change of the sunk firing costs $(d F)$

$$
\begin{gathered}
\mathrm{dp}_{\text {exit }}^{\mathrm{u}}=0 \Leftrightarrow \mathrm{dw}=\frac{\mathrm{i}}{1+\mathrm{i}} \cdot \mathrm{dF}+\frac{\mathrm{du}}{1+2 \mathrm{i}} \\
(\text { for } i=10 \%: d w=0.833333 d u+0.090909 d F)
\end{gathered}
$$

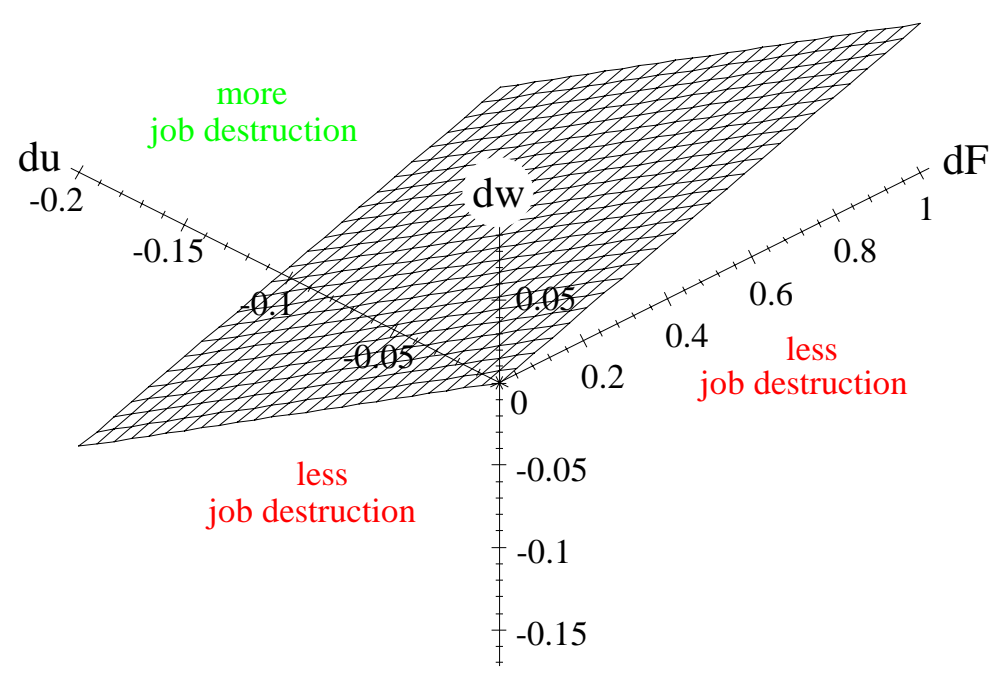

Comment on Fig. 8: Above the indifference plane $p_{\text {exit }}^{\mathrm{u}}$ increases. Thus, the extent of job destruction is higher in this area. In contrast, existing jobs are "protected" in the area below the indifference space. Jobs are destroyed to a lower extent.

Here, we assume a reduction of uncertainty and at the same time an increase of wage costs, which promotes job destruction. However, this scenario is contrasted with a stronger protection of existing jobs by an increase of the firing costs. Hence, also in this case the final effect is a priori not exactly identified. Since two effects work into the same direction it can be assumed to be more realistic than in the above hiring scenario (depicted in Fig. 7) to assume a position above the indifference plane. In other words and seen on the whole, the tendency towards job destruction may be stronger than the one towards job creation. As a consequence, a "Mezzogiorno/Eastern Germany" scenario would be the result. ${ }^{20}$

\section{Summary}

We discuss the effect of an adoption of the EU acquis communautaire on future labor market performance in the CEECs. For this purpose, we model and investigate the impact of institutional uncertainty (and of its elimination) on job creation and job destruction in these

20 However, see the caveats as expressed in fn. 19. 
countries. We conclude that the structural change on CEEC labor markets is fostered via reducing institutional uncertainty. However, the adoption of inefficient EU social and labor policy regulations might also entail significant risks for employment. Based on a real option value analysis, we investigate and evaluate the trade-off between lower institutional uncertainty and higher employment costs.

\section{References}

Baldwin, R. E., François, J., Portes, R. (1997). The Costs and Benefits of Eastern Enlargement: The Impact on the EU and Central Europe, Economic Policy, 24, 125-176.

Belke, A. (1998). Maastricht - Implications of a Centralized Monetary and Currency Policy for Employment in Europe, in Addison, J. T. and P. J. J. Welfens (eds.), Labor Markets and Social Security - Wage Costs, Social Security Financing and Labor Market Reforms in Europe, Berlin.

Belke, A., Göcke, M. (1994). Starke Hysteresis auf dem Arbeitsmarkt, ZWS - Zeitschrift für Wirtschafts- und Sozialwissenschaften, 114, 345-377.

Belke, A., Göcke, M. (1998). Micro- and Macro-Hysteresis in Employment under Exchange Rate Uncertainty, Institut für Europäische Wirtschaft (IEW) Discussion Paper no. 23, Bochum University, March 1998. Paper presented at the fifth international conference on 'Computing in Economics and Finance' (CEF'99) at Boston College, MA.

Belke, A., Göcke, M. (1999). A Simple Model of Hysteresis in Employment under Exchange Rate Uncertainty, Scottish Journal of Political Economy, 46, 260 - 286.

Belke, A., Hebler, M. (2000). EU Enlargement and Labour Markets in the CEECs, Intereconomics, $35,219-230$

Belke, A., Hebler, M. (2001). Social Policy and Eastern Enlargement of the EU: Labor Market Impacts for the Accession Countries, Journal for Institutional Innovation, Development and Transition, 5, 48-61.

Belke, A., Hebler, M. (2002). Towards a European Social Union: Impacts on Labor Markets in the Acceding CEECs, Constitutional Political Economy, 13, 313-335.

Bell, J., Mickiewicz, T. (1999). EU Accession and Labour Markets in the Visegrad Countries, in Henderson, K. (ed.), Back to Europe: Central and Eastern Europe and the European Union, London.

Bentolila, S., Bertola, G. (1990). Firing Costs and Labour Demand: How Bad is Eurosclerosis? Review of Economic Studies, 57, 381-402.

Biffl, G. (1998). Comments to the Paper of Tito Boeri on Labour Markets and Enlargement, paper presented at the 25 Years Anniversary Conference "Shaping the New Europe: Challenges of Eastern Enlargement - East and West European Perspectives, Vienna Institute for International Economic Studies, 11 to 13 November, Vienna.

Boeri, T. (1998). Labor Markets and EU Enlargement, paper presented at the 25 Years Anniversary Conference "Shaping the New Europe: Challenges of Eastern Enlargement - East and West European Perspectives, Vienna Institute for International Economic Studies, 11 to 13 November, Vienna.

Boeri, T., Burda, M. C., Köllö, J. (1998). Mediating the Transition: Labor Markets in Central and Eastern Europe, Centre for Economic Policy Research: Forum Report of the Economic Policy Initiative No. 4, London.

Boeri, T., Terrell, K. (2002). Institutional Determinants of Labor Reallocation in Transition, in: Journal of Economic Perspectives, 16/1, 51-76. 
Burda, M. C. (1998). The Consequences of EU Enlargement for Central and East European Labour Markets, CEPR Discussion Paper, No. 1881, London.

Cox, J.C., Ross, S.A., Rubinstein, M. (1979). Option Pricing: A Simplified Approach, Journal of Financial Economics, 7, 229-263.

Dixit, A. (1989). Entry and Exit Decisions under Uncertainty, Journal of Political Economy, 97, 620638.

Dixit, A., Pindyck, R S. (1994). Investment under Uncertainty, Princeton, NY.

Dornbusch, R. (1987). Open Economy Macroeconomics: New Directions, NBER Working Paper no. 2372, August 1987.

Feldmann, H. (1999). Zehn Jahre EU-Sozialcharta, Wirtschaftsdienst, 79, 670-676.

Franz, W. (1995). Central and East European Labour Markets in Transition: Developments, Causes, and Cures, CEPR Discussion Paper No. 1132, Centre for Economic Policy Research, London.

Göcke, M. (1994). Micro- and Macro-Hysteresis in Foreign Trade, Aussenwirtschaft - Schweizerische Zeitschrift für internationale Wirtschaftsbeziehungen, 49 (IV), 555-578.

Gros, D. (1987). Exchange Rate Variability and Foreign Trade in the Presence of Adjustment Costs. Département des Sciences Economiques, Working Paper no. 8704, Louvain-la-Neuve.

Guiso, L., Parigi, G. (1997). Investment and Demand Uncertainty. Ente "Luigi Einaudi" and Reasearch Department Banca d'Italia, Rome, mimeo, September 1997.

Heise, A. (1998). Europäische Sozialpolitik - Eine Einschätzung aus gewerkschaftlicher Sicht, Forschungsinstitut der Friedrich-Ebert-Stiftung, Gesprächskreis Arbeit und Soziales, Bonn.

http://conventions.coe.int/Treaty/EN/cadreprincipal.htm

Huber, P. (1999). Labour Market Adjustments in Central and Eastern Europe: How Different? Paper presented at the Annual EALE Conference, 23. - 26.09.99, Regensburg.

Jovanovic, M. N. (1999). What Are the Limits to the Enlargement of the European Union? Journal of Economic Integration, 14, 467-496.

Kohler, W. (1999). Wer gewinnt, wer verliert durch die Osterweiterung der EU?, Invited Lecture at the Annual Conference of the German Economic Association, September 28 to October 1, Mainz.

Krugman, P. (1989). Exchange Rate Instability. MIT Press, Cambridge/MA.

Lavigne, M. (1998). Conditions for Accession to the EU, Comparative Economic Studies, 40, 38-57.

Martens, B. (2000). The Performance of the EC Phare Programme as an Instrument for Institutional Reform in the EU Candidate Member States, Paper presented at the $4^{\text {th }}$ International IMAD Conference Institutions in Transition, 23 to 24 June, Portoroz (Slovenia).

Nickell, St. J., Bell, B. (1997). Would Cutting Payroll Taxes on the Unskilled have a Significant Impact on Unemployment? In Snower, D. J. (ed.) Unemployment Policy - Government Options for the Labour Market, 296-328.

OECD (1999). Employment Outlook, Paris.

Pindyck, R.S. (1988). Irreversible Investment, Capacity Choice and Uncertainty, American Economic Review, 78, 969-985.

Pindyck, R.S. (1991). Irreversibility, Uncertainty, and Investment, Journal of Economic Literature, 29, 1110-1148.

Riboud, M., Sánchez-Páramo, C., Silva-Jáuregui, C. (2002). Does Eurosclerosis Matter? Institutional Reform and Labor Market Performance in Central and Eastern European Countries in the 1990s, World Bank Social Protection Discussion Paper No. 0202.

Sinn, H.-W. (1999). EU-Enlargement, Migration and Lessons from German Unification, CEPR Discussion Paper, No. 2174, Centre for Economic Policy Research, London. 